\title{
Constraints Perceived by the Farmers of Himachal Pradesh in Organic Farming
}

\author{
Nisha Devi*1 ${ }^{* 1}$ Krishan Kumar Raina ${ }^{2}$ and Ravinder Sharma ${ }^{3}$
}

${ }^{1}$ Post Doctoral Fellow (ICSSR, New Delhi), Dr. Y.S. Parmar University of Horticulture and Forestry Nauni, Solan, HP, India ${ }^{2}$ Department of Business Management, Dr. Y.S. Parmar University of Horticulture and Forestry Nauni, Solan, HP, India ${ }^{3}$ Department of Social Sciences, Dr. Y.S. Parmar University of Horticulture and Forestry Nauni, Solan, HP, India

"Corresponding author: nishathakuroachghat@gmail.com (ORCID ID: 0000-0002-7180-4749)

Received: $11-01-2020$

Revised: $14-04-2020$

Accepted: $22-05-2020$

\begin{abstract}
Organic farming is one among the broad spectrum of production methods that are supportive of the environment through minimizing the use of chemical inputs and through use of on-farm resources efficiently. The present study was conducted in all the four zones of Himachal Pradesh with one representative district from each zone. Three blocks from each district was selected and from each block 12 organic farmers were selected. Thus, a sample size of 144 organic farmers was selected from all the four agro-climatic zones of Himachal Pradesh. Pre- tested schedule was used to collect relevant information from the farmers. Garret ranking technique was employed to prioritize the imminent constraints like production, marketing and ecological constraints. Highly severe constraints that were being faced by the farmers-practicing organic farming in the study area were small land holding, decline in crop productivity, higher incidence of pests and diseases, non availability of market place, lack of minimum support prices for organic products, wild animals menace, less erratic monsoon, fluctuation in temperature and humidity. These factors highlight the weak links, which need to be strengthened for promoting organic farming widely.
\end{abstract}

\section{Highlights}

(0 Highly severe constraints with the highest Garret Mean score in Himachal Pradesh were non availability of market for organic produce (84.00) followed by small land holdings (80.06).

Keywords: Organic farming, Garrett's ranking, production constraints, marketing constraints, ecological constraints

Himachal Pradesh is one of the hill states of India which lies in the western Himalaya. Agriculture is way of life, a tradition which for centuries has shaped the thought, the outlook, the culture and economic life of Himachalis. Himachal Pradesh is the only State in the country whose 89.96 per cent population lives in rural areas. Therefore dependency on Agriculture/ Horticulture is eminent as it provides direct employment to about 69 per cent of total workers of the State (Economic Survey of Himachal Pradesh, 2019-20). As part of their subsistent farming operations farmers in Himachal Pradesh have been traditionally dependent on organic ways of farming. Over the decades, it resulted in success stories of viable farming by small hill farmers on their marginal farmlands, until the time when farmers started experiencing new problems, decline in organic matter of the farmlands, increasing pest incidence of ever new kinds, increasing cost of cultivation, climate change based impacts on agriculture etc. To counter these problems and increase the productivity, farmers of

How to cite this article: Devi, N., Raina, K.K. and Sharma, R. (2020). Constraints perceived by the farmers of Himachal Pradesh in organic farming. Economic Affairs, 65(2): 213-218.

Source of Support: None; Conflict of Interest: None 
the state started using the synthetic form of nutrients that are found deficient in soil or kill the pest and weed with poisonous pesticides \& weedicides. This resulted in damaged soils, expensive and needless farming inputs, water-intensive/water-pollutive, lethal and ecologically harmful farming practices (all of which emanate from chemical farming) and do no good to agricultural advancement and to public health. Modern organic farming is thus being developed as a response to the environmental harm caused by the use of chemical pesticides and synthetic fertilizers in conventional agriculture. The growth of organic farming is relatively slower despite the fact that it is the best solution to the environmental problems such as climate change, health and sustainability issues that we are facing today due to conventional farming. In hill regions, small farm holders face a number of constraints in practicing organic farming. The major constraints faced by them were economic and marketing including initial low price for the organic produce, lack of specialized market, initial yield loss and high transportation cost. These constraints need to be overcome by appropriate interventions.

Sharma and Pathania (2011) explained that there is a growing awareness among the dry temperate hill farmers to cultivate crops under organic farming system because of escalating cost of inorganic fertilizers, decreased soil fertility, environmental and health hazards due to pesticide uses and expected premium prices for organically produced crops. There were also many factors which act as deterrents for organic farming. The present analysis is based on such factors. The identification of such factors highlights the weak links, which need to be strengthened for promoting organic farming widely. The analysis is pre-dominantly based on the responses of organic farmers.

\section{DATA AND METHODOLOGY}

Primary Data were collected from the organic farmers of all the four agro-climatic zones of Himachal Pradesh for the agricultural year 2019. One district from each agro-climatic zone was selected purposively. Una (Shivalik Hill Zone), Solan (Mid Hill Zone), Shimla (High Hill Zone) and Kinnaur (Cold Dry Zone) districts were chosen. Three blocks from each selected district were purposively selected, on the basis of maximum area under organic farming in consultation with district level officers, then accordingly four villages from each block was chosen purposively. After selection of village, three organic farmers were selected randomly from each village. Accordingly, 12 households were selected from each block thus making total sample size of 144 organic farmers from four agro-climatic zones of Himachal Pradesh. For the selection of sample, three stage stratified random sampling design was adopted; with development block as a primary unit, village as a secondary unit and sampled farmer as an ultimate unit. Garrett's Ranking Technique was used to prioritize the imminent challenges/constraints.

\section{Garrett's Ranking Technique}

Per cent Position $=100\left(R_{i j}-0.50\right) / N_{i j}$

Where, $R_{i j}=$ Rank given to the $i^{\text {th }}$ item by the $j^{\text {th }}$ individual,

$N_{i j}=$ Number of items ranked by the $j^{\text {th }}$ individual, The per cent position of each rank was converted into scores using Garrett's table. For each constraint score of the individual respondent were added. Thus, mean score for each constraint was ranked by assigning higher rank (1) to highest value of Garrett mean score.

\section{RESULTS AND DISCUSSION}

\section{Constraints/ Challenges}

Important constraints being faced by farmers practicing organic farming systems in the selected area are divided into four major categories ie Production constraints, Marketing constraints, Ecological constraints and other than these in Other constraints,are presented in table $-1,2,3$ and 4 .

Production constraints: It may be seen that at overall level small land holding was reported as major constraint with rank 1 (Table 1). It was also highly severe problems in zone-III and zone-IV. There is a preponderance of small land holdings in Himachal Pradesh. According to Agricultural Census of Himachal Pradesh (2010-11), small and marginal farmers together constitute $88 \%$ of the total population of the state. The average size of holding was 1.0 hectares in 2010-11. Second largest constraint being faced by organic farmers is decline in crop productivity for which farmers 
Table 1: Production constraints being faced by the farmers in the study area

\begin{tabular}{|c|c|c|c|c|c|c|c|c|c|c|c|}
\hline \multirow{2}{*}{$\begin{array}{l}\text { Sl. } \\
\text { No. }\end{array}$} & \multirow{2}{*}{ Constraints } & \multicolumn{2}{|c|}{ Zone-I } & \multicolumn{2}{|c|}{ Zone-II } & \multicolumn{2}{|c|}{ Zone-III } & \multicolumn{2}{|c|}{ Zone-IV } & \multicolumn{2}{|c|}{ Over all } \\
\hline & & GMS* & Rank & GMS* & Rank & GMS* & Rank & GMS $^{*}$ & Rank & GMS* $^{*}$ & Rank \\
\hline 1 & Small land holding & 80.50 & II & 80.81 & III & 79.58 & I & 79.36 & I & 80.06 & I \\
\hline 2 & Decline in crop productivity & 78.67 & IV & 84.17 & I & 79.28 & II & 77.14 & II & 79.81 & II \\
\hline 3 & Non availability of seed material & 64.00 & XIV & 59.86 & $\mathrm{XV}$ & 67.72 & XIII & 66.61 & XIII & 64.54 & XIV \\
\hline 4 & Non availability of organic manures & 68.92 & VII & 62.94 & XII & 68.47 & XI & 75.17 & III & 68.87 & $\mathrm{X}$ \\
\hline 5 & Non availability of biopesticides & 64.00 & $\mathrm{XV}$ & 60.44 & XIII & 65.42 & XV & 64.39 & $\mathrm{XV}$ & 63.56 & $\mathrm{XV}$ \\
\hline 6 & Higher incidence of pests and diseases & 80.50 & III & 80.19 & IV & 77.75 & IV & 70.50 & IX & 77.23 & III \\
\hline 7 & Non availability of water for irrigation & 86.00 & I & 81.72 & II & 75.61 & VI & 65.06 & XIV & 77.09 & IV \\
\hline 8 & Less-fertile soil & 67.36 & XI & 70.72 & VIII & 65.53 & XIV & 70.11 & $\mathrm{X}$ & 68.43 & XI \\
\hline 9 & Costly labour & 75.31 & VI & 79.58 & V & 78.67 & III & 72.33 & VI & 76.47 & $\mathrm{~V}$ \\
\hline 10 & Lack of skilled labour at operation period & 68.28 & VIII & 67.06 & $\mathrm{X}$ & 70.72 & VIII & 73.64 & IV & 69.92 & VIII \\
\hline 11 & Lack of information on organic farming & 67.78 & $\mathrm{X}$ & 65.53 & XI & 68.14 & XII & 70.75 & VIII & 68.05 & XII \\
\hline 12 & Lack of technical guidance & 67.11 & XII & 67.36 & IX & 72.72 & VII & 71.33 & VII & 69.63 & IX \\
\hline 13 & Lack of awareness about organic practices & & & & & & & & & & \\
\hline & to control the pest and diseases & 66.14 & XIII & 78.14 & VI & 69.97 & $\mathrm{x}$ & 72.86 & $\mathrm{~V}$ & 71.77 & VII \\
\hline 14 & Think that local conditions are conducive & & & & & & & & & & \\
\hline & for inorganic farming & 67.97 & IX & 60.00 & XIV & 70.72 & IX & 67.06 & XII & 66.43 & XIII \\
\hline 15 & Fluctuating production & 76.83 & $\mathrm{~V}$ & 71.50 & VII & 76.22 & $\mathrm{~V}$ & 69.19 & XI & 73.43 & VI \\
\hline
\end{tabular}

GMS*- Garret Mean Score.

Table 2: Marketing constraints being faced by the farmers in the study area

\begin{tabular}{|c|c|c|c|c|c|c|c|c|c|c|c|}
\hline \multirow{2}{*}{\multicolumn{2}{|c|}{ S1. No. Constraints }} & \multicolumn{2}{|c|}{ Zone-I } & \multicolumn{2}{|c|}{ Zone-II } & \multicolumn{2}{|c|}{ Zone-III } & \multicolumn{2}{|c|}{ Zone-IV } & \multicolumn{2}{|c|}{ Over all } \\
\hline & & GMS* & Rank & GMS* & Rank & GMS* & Rank & GMS* & Rank & GMS* & Rank \\
\hline 1 & Lack of all weather roads & 63.61 & $\mathrm{X}$ & 64.33 & $\mathrm{X}$ & 67.83 & XI & 80.39 & II & 69.04 & IX \\
\hline 2 & Inadequate storage facilities & 77.28 & V & 71.94 & VII & 77.17 & $\mathrm{~V}$ & 77.83 & IV & 76.06 & $\mathrm{~V}$ \\
\hline 3 & Price instability & 77.56 & IV & 77.44 & II & 77.06 & VI & 73.78 & IX & 76.46 & IV \\
\hline 4 & High transport charges & 69.28 & VIII & 73.83 & VI & 80.22 & IV & 77.61 & V & 75.24 & VII \\
\hline 5 & Distant markets & 78.17 & III & 75.78 & V & 81.50 & II & 78.44 & III & 78.47 & III \\
\hline 6 & $\begin{array}{l}\text { Malpractices by traders at the time of } \\
\text { auction }\end{array}$ & 69.56 & VII & 67.25 & VIII & 75.06 & VII & 77.17 & VI & 72.26 & VIII \\
\hline 7 & Lack of availability of institutional credit & 68.33 & IX & 64.03 & XI & 65.94 & XI & 64.78 & XIII & 65.77 & XI \\
\hline 8 & Lack of market intelligence & 62.00 & XII & 62.81 & XII & 65.33 & XII & 67.81 & XII & 64.49 & XII \\
\hline 9 & Non-assurance of getting income & 76.00 & VI & 76.47 & IV & 73.72 & VIII & 75.06 & VIII & 75.31 & VI \\
\hline 10 & $\begin{array}{l}\text { Lack of minimum support prices for } \\
\text { organic products }\end{array}$ & 79.33 & II & 77.33 & III & 80.67 & III & 76.78 & VI & 78.53 & II \\
\hline 11 & Inaccurate weighing instruments. & 62.00 & XIII & 61.25 & XIII & 62.00 & XIII & 67.92 & XI & 63.29 & XIII \\
\hline 12 & $\begin{array}{l}\text { Non availability of market place } \\
\text { exclusively for organic produce }\end{array}$ & 84.00 & I & 84.00 & I & 84.00 & $\mathrm{I}$ & 84.00 & $\mathrm{I}$ & 84.00 & $\mathrm{I}$ \\
\hline 13 & High commission charges & 62.28 & XI & 67.08 & IX & 69.06 & IX & 72.33 & $X$ & 67.69 & $X$ \\
\hline
\end{tabular}

GMS*- Garret Mean Score.

should always be ready to take risk. This constraint was also found as major constraint with rank I \& II in different zones. Higher incidence of pests and diseases was the third largest constraint at state level expressed by the farmers. It was found more severe in three zones i.e., zone-I, zone-II and zone-III. The pests and diseases management with organic means is complex and needs holistic and systematic approach. The capacity building on these aspects needs to be addressed through various research and extension programmes and should be pest and location specific. There were also several other constraints like non availability of water for irrigation, costly labour, fluctuating production, Lack of awareness about organic practices to control the pest and diseases etc which were ranked in their ascending order as $4^{\text {th }}, 5^{\text {th }}, 6^{\text {th }}$ and so on respectively.

Marketing constraints: In organic farming most important constraint reported by the farmers that they were facing was the problem of marketing. Non availability of market place exclusively for organic produce was the major constraint with rank I in all the four zones of Himachal Pradesh (Table 2). Almost all the farmers in the study area expressed their anguish for lack of marketing facilities. Prabu (2008) stated that the lack of genuine 
marketing infrastructure was a big problem for the growers. Though organic farming has been proved to be low investment technology for growing crops, marketing organically produced crops has not been an easy task especially for some farmers. $\mathrm{He}$ also opined that lack of information on marketing channels and absence of proper governmental guidelines has forced many of them to sell their produce for a throwaway price. Roshan (2010) stated that the problems encountered in the marketing of organic produce have also hindered its growth in the country. It is very important that organic produce is marketed at a premium price over conventional produce, so that it becomes viable for farmers to adopt these methods regularly on a large scale. There is huge international demand for organic produce, but so far, the output in India has been insufficient to meet this demand. Lack of minimum support prices for organic products is playing their role in proving a constraint for organic farming and is hence, ranked second. Bishnoi et al. (2020), conducted a study in Kurukshetra and Panipat districts of eastern zone and Hisar district of western zone in the state of Haryana. These districts were selected on basis of acreage under summer mungbean. The analysis of constraints in cultivation of summer mungbean as opined by the sampled farmers recite that non-availability of suitable machine for harvesting, non-procurement of produce by Govt. agencies, harvest price less than MSP were recorded as the major constraints in the study area. Distant markets, price instability and inadequate storage facilities were another highly severe problems related to marketing which were ranked $3^{\text {rd }}, 4^{\text {th }}$ and $5^{\text {th }}$ respectively at state level in the study area. Price fluctuation is a multifaceted problem attributed by various factors which, when combined, culminate in dangerous consequences for the most vulnerable. Although high prices can technically be good news for farmers, price fluctuation is extremely dangerous, as farmers and other agents in the food chain risk losing their investments if prices fall. Traditional harvesting and storage conditions of Indian farms and farmers result in large proportions of crop wastage. It has been estimated that crop wastage due to inefficient storage is 7 per cent of annual grain production per year in India. This percentage accounts for 21 million tonnes of wheat grain alone, as India lacks proper cold storage and cold chain transportation (Suprem et al. 2013). These affected the promotion of organic farming. There are a number of constraints impeding small farm holders in India for adopting organic farming. Major apprehension lies in non-availability of sufficient amount of organic supplements, biofertilizers and local market for organic produce (Pandey and Singh, 2012, Samantaray et al. 2009). Mohanty et al. (2013) have also reported the major constraints like lack of regular soil testing, lack of mechanization in agriculture, poor knowledge of IPM, lack of innovativeness, lack of entrepreneurial ability, lack of low responsiveness, absence of storage facilities, postharvest technologies and lack of effective supervision and monitoring by extension workers for adoption of technologies for vegetable production being perceived by the tribal farmers of north Sikkim.

Ecological constraints: The farming community is facing several threats due to environmental changes and pollution. Crop damages due to climatic changes are putting a lot of pressure on the farmers. The cultivation of high value crops, especially horticultural crops, has started showing increasing symptoms of unsustainability due to, among other things, falling soil fertility, erratic weather conditions and the emergence of numerous insects, pests and diseases. The adoption of same cropping sequence year after year has caused the loss of micronutrients leading to deterioration in the overall soil health. Land use pattern in the state of Himachal Pradesh in the Indian Western Himalayas has been undergoing rapid modifications due to changing cropping patterns, rising anthropogenic pressure on forests and climate changes. In the study area irregular monsoon showed a deep impact in all the zones (Table 3). Monsoon plays a crucial role in Indian agriculture. Most farmers rely on good crop produce during monsoon to earn their living and in order to overcome debts incurred. This further cements the importance of monsoon in an agrarian economy like India. Agriculture in Himachal too is largely dependent on monsoon and as such production of crops fluctuates year after year due to irregular monsoon. At the state level, problem of irregular monsoon has thus been ranked first. Fluctuation in temperature and humidity was also found out to be a major constraint in study area and was ranked second instate as well as at individual zones. 
Table 3: Ecological challenges related to farming being faced by the farmers in the study area

\begin{tabular}{|c|c|c|c|c|c|c|c|c|c|c|c|}
\hline \multirow{2}{*}{$\begin{array}{l}\text { Sl. } \\
\text { No. }\end{array}$} & \multirow{2}{*}{ Constraints } & \multicolumn{2}{|c|}{ Zone-I } & \multicolumn{2}{|c|}{ Zone-II } & \multicolumn{2}{|c|}{ Zone-III } & \multicolumn{2}{|c|}{ Zone-IV } & \multicolumn{2}{|c|}{ Over all } \\
\hline & & GMS* & Rank & GMS* & Rank & GMS* & Rank & GMS* & Rank & GMS* & Rank \\
\hline 1 & Climate not suitable & 76.33 & III & 74.22 & III & 65.64 & IV & 54.08 & V & 67.57 & III \\
\hline 2 & Soil erosion & 51.53 & VII & 52.97 & VII & 60.31 & VI & 65.33 & I & 57.53 & VI \\
\hline 3 & Loss of water holding capacity & 53.78 & $\mathrm{~V}$ & 53.75 & VI & 57.00 & VII & 52.19 & VI & 54.18 & VII \\
\hline 4 & $\begin{array}{l}\text { Soil contamination with Pesticides } \\
\text { and others }\end{array}$ & 51.78 & VI & 61.42 & V & 65.56 & $\mathrm{~V}$ & 51.33 & VII & 57.52 & $\mathrm{~V}$ \\
\hline 5 & $\begin{array}{l}\text { Less erratic monsoon or the } \\
\text { distribution of rains is not as per the } \\
\text { requirements. }\end{array}$ & 78.00 & I & 77.67 & I & 74.67 & I & 64.67 & II & 73.75 & I \\
\hline 6 & $\begin{array}{l}\text { Fluctuation in temperature and } \\
\text { humidity }\end{array}$ & 78.00 & II & 75.67 & II & 73.00 & II & 60.44 & III & 71.78 & II \\
\hline 7 & Wind and hail storms & 72.25 & IV & 62.53 & IV & 70.58 & III & 60.36 & IV & 66.43 & IV \\
\hline
\end{tabular}

GMS*- Garret Mean Score.

Table 4: Other constraints related to farming being faced by the farmers in the study area

\begin{tabular}{|c|c|c|c|c|c|c|c|c|c|c|c|}
\hline \multirow{2}{*}{$\begin{array}{l}\text { Sl. } \\
\text { No. }\end{array}$} & \multirow{2}{*}{ Constraints } & \multicolumn{2}{|c|}{ Zone-I } & \multicolumn{2}{|c|}{ Zone-II } & \multicolumn{2}{|c|}{ Zone-III } & \multicolumn{2}{|c|}{ Zone-IV } & \multicolumn{2}{|c|}{ Over all } \\
\hline & & GMS* & Rank & GMS* & Rank & GMS* & Rank & GMS* & Rank & GMS* & Rank \\
\hline 1 & No local processing facilities & 68.56 & II & 64.11 & II & 59.22 & III & 66.33 & I & 64.56 & II \\
\hline 2 & Wild animals menace & 70.81 & I & 69.89 & I & 68.56 & I & 49.67 & IV & 64.73 & I \\
\hline 3 & $\begin{array}{l}\text { Certification process is expensive } \\
\text { and complicated }\end{array}$ & 43.00 & IV & 35.33 & IV & 47.28 & IV & 56.72 & III & 45.58 & IV \\
\hline 4 & Too technical & 45.56 & III & 55.61 & III & 59.44 & II & 58.33 & II & 54.74 & III \\
\hline
\end{tabular}

GMS*- Garret Mean Score.

Other constraints: Wild animals menace was found as the major constraint at state and also in different agro climatic zones with the highest mean score (Table 4). The menace of wild and stray animals has emerged as one of the greatest challenges in the recent past. Damage to crops by wild and stray animals specially monkeys is being reported from many parts of the state. The issue has been highlighted even at the legislative assembly many times. The farmers are facing the crop damage problems due to the crop raiding by wild animals. Secondly, there were no local processing facilities available in the study area. Consumption of processed products started since time immemorial. Agricultural product processing plays an important role in food and its preservation. The agro processing unit focuses on product research and development for the transformation of local produce into value added agricultural products as well as the transfer of technology for agri business development to improve income generation and food security but due to lack of local processing units in the study area, the farmers are unable to reap these benefits.

\section{CONCLUSIONS}

It is evident from the study that the transition towards organic farming is not without constraints, especially for small land holders. Thus, for encouraging the production and efficient marketing of organic crops, various problems and constraints in their production and marketing with which they are confronted with, were identified. There were many factors which act as deterrents for organic farming. The highly severe production constraints being faced by the farmers in the study area were small land holding, decline in crop productivity, higher incidence of pests and diseases, non availability of water for irrigation and costly labour which were rankled $1^{\text {st }}, 2^{\text {nd }}, 3^{\text {rd }}$, $4^{\text {th }}$ and $5^{\text {th }}$ by using Garret ranking method. The study has confirmed that marketing constraints like non availability of market place $\left(1^{\text {st }}\right)$, lack of minimum support prices for organic products $\left(2^{\text {nd }}\right)$ and distant markets $\left(3^{\text {rd }}\right)$ were significantly associated with the organic crop production. Major ecological constraints found in the study area were irregular monsoon and fluctuation in temperature 
AESSRA

Devi et al.

and humidity. Other emerging challenges like wild animals menace and lack of local processing facilities pose a serious threat to the economic viability and ecological sustainability of the process of crop production in the state. If these constraints are removed by effective planning and its execution at ground level, the results can be fruitful both for the farmers as well as the economy as whole.

\section{ACKNOWLEDGEMENTS}

I would like to express my thanks to Indian Council of Social Science Research, New Delhi (ICSSR) for providing me financial assistance to carry out this study.

\section{REFERENCES}

Bishnoi, D.K., Malik, D.P., Pawar, N., Kumar, N. and Sumit. 2020. Resource use efficiency and constraint analysis of summer mungbean cultivation in rice-wheat cropping system. Economic Affairs, 65(1): 117-122.

Mohanty, A.K., Lepcha, B. and Kumar, A. 2013. Constraints analysis in adoption of vegetable production technologies for livelihood perspective of tribal farmers in North Sikkim. Indian Research Journal of Extension Education, 13(2): 51-56.
Pandey, J. and Singh, A. 2012. Opportunities and constraints in organic farming: An Indian perspective. Journal of Scientific Research, 56: 47-72.

Prabu, M.J. 2008. Only market driven strategies can boost organic farming. The Hindu, Business line, Online Edition, March 6, 2008.

Roshan, P.M. 2010. Organic agriculture in India.www. chillbreeze.com. accessed on March 252010.

Samantaray, S.K., Prusty, S. and Raj, R.K. 2009. Constraints in vegetable production-experiences of tribal vegetable growers. Indian Research Journal of Extension Education, 9(3): 32-34.

Sharma, S.K. and Pathania, A. 2011. Status of organic farming in dry temperate region of Himachal Pradesh. National Symposium cum Brainstorming Workshop on Organic Agriculture, April 19-20, 2011, p.70.

Suprem, A.N., Mahalik and Kim, K. 2013. A review on application of technology systems, standards and interfaces for agriculture and food sector. Computer Standards and Interfaces, 35: 355-364. 